\title{
Role of Garlic and Turmeric Extract in The Leaves Mineral Contents of Apple Trees
}

\author{
Mustafa E.A.Al-Hadethi ${ }^{1}$, M. H. Sh. Al-Hamdany2, AliS.T. AL-Dulaimi ${ }^{3}$ \\ ${ }^{I}$ Instructor. Dep. of Horticulture, College of Agriculture, University of Baghdad, Iraq. \\ ${ }^{2}$ Instructor.Date Palm Research Unit, College of Agriculture, University of Baghdad, Iraq. \\ ${ }^{3}$ Assist Instructor. Dep.of Biology. Al-Rasheed University College.
}

\begin{abstract}
This research was conducted in the Apple orchard belong to Department of Horticulture / Collage of Agriculture / University of Al-Anbar-Abu Ghraib during 2015 and 2016 seasons in order to investigate the response of four years old Apple trees (CV.Anna) budded on seeding root stock to foliar application with turmeric extract at four levelsO $\left(T_{0}\right), 1.5$ g. $L^{-1}\left(T_{1.5}\right), 3$ g. $L^{-1}\left(T_{3}\right)$ and 4.5 g. $L^{-1}\left(T_{4.5}\right)$ and garlic extract at four levels, $O\left(G A_{0}\right), 25 \mathrm{ml} . L^{-1}\left(G A_{25}\right), 50 \mathrm{ml} . L^{-1}\left(G A_{50}\right)$ and $100 \mathrm{ml} . L^{-1}\left(G A_{100}\right)$ and their interaction between them in leaves mineral content . Each treatment replicated three times with a factorial experiment using RCBD. The number of trees used was 48 trees. The results showed that the interaction between the garlic extract at $100 \mathrm{ml}$ .$L^{-1}$ combined with turmeric extract at $4.5 \mathrm{~g} . L^{-1}\left(G_{100} T_{3}\right)$ gave a high value of leavesnitrogen content at 1.99 and $2.06 \%$, potassium content at 2.09 and $2.13 \%$, iron contentat 210.2 and $214.4 \mathrm{ppm}$ and high value of leaveszinc content at and zinc 23.54 and 25.53 ppmfor both seasons, respectively. The lowest value of these parameters was found in the control $\left(G A_{0} T_{0}\right)$ treatment.
\end{abstract}

\section{Introduction}

Apple (MalusdomesticaBorkh) is an important member of family Rosaceae and grown widely throughout the world. As originally grew up in the southern Caucasus region, it has been found in East Asia for thousands of years (Bright, 2005). The acreage of apple in the world reached about 4842822 hectare, with production of 76378738tons (FAO, 2012).The main producing countries are China then United States of America, Turkey,Poland, India (FAO, 2012).The estimated number of apple fruit trees in Iraq, including nearly 1952970 tree produces up to 62433 tons, and the average production per tree about $32.0 \mathrm{~kg}$ (PCBS, 2013).The use of natural products in horticultural practices instead of synthetic chemical products is becoming as a main target for many fruit crop producers, where the world market has been growing rapidly in recent years for organic fruit production (Dimitri and Oberholtzer, 2006).

Turmeric Curcuma longa $\mathrm{L}$. is an herbaceous perennial plant belonging to the Zingiberaceae family.Curcuma genus contains about 30 species. It originates from India and South East Asia and cultivated in the majority of tropical countries. It is obtained from the rhizome of Curcuma longa. It contains 2 to $9 \%$ curcuminiods which contains $60 \%$ curcumin, Curcumin oxidation yield vanillin. Turmeric extract is rich in carbohydrates, (50\% starch), arabinogalacton, potassium salt, essential oils and pigments. It is known for its anti- inflammatory, anti- oxidant and anti- microbial properties. Curcumin has a free radical scavenger activity namely hydroxyl radical that is responsible to protect DNA from damage and inhibit lipid peroxidation (Srimal, 1997 and Alonso, 2004).Ahmed et al., 2014, studied the effect of turmeric extract used as a foliar spray on leaf mineral content in mango trees. Found a significant increase in leaf N, P, K content. In addition, Al-Hadethi and Al-Kubaisy (2015) found that spraying peach with turmeric extract gave the highest value in leaf N, P, K content.Garlic (Allium sativum) extract contains enzymes and more than 200 chemical compounds, some of its volatiles are more important i.e.Allicin that gives garlic its antibiotic properties. Its higher contents ofvolatile and sulphur compounds put both in the top due to their realand essential roles they play in fruiting process of various fruit trees (Bruneton, 2001). Garlic also contains vitamins, minerals, flavonoids, ascorbic acid, sulphur and trace of iodine. Seventeen amino acids are found in garlic, including eight essential ones. Effect of garlic extract on leaves mineral content has been interpreted byAbd El-Hamied and El-Amary (2015) and El-Sharony et al. (2015). They reported that garlic extract showed comparativelygreater efficacy on nutrition status of pear and mango respectively. The target of this study was to evaluate leaves mineral content of "Anna" apple cultivar under using turmeric and garlic extract under Iraq conditions.

\section{Materials and Methods}

This study was conducted in the appleorchard; Horticultural Department, College of Agriculture University of AL-Anbar during 2015 / 2016 growing seasons to investigate the influence of garlic extract and turmeric extract spray on 4 year's old trees of "Anna" apple cultivar. Trees were cultivated at $3 \times 3 \mathrm{~m}$ apart under basin irrigation system. Trees were healthy, similar in vigor and subjected to the same horticultural 
practices adapted in the region. This study included the following treatment: four levels of sprayingof turmeric extract, $0\left(\mathbf{T}_{0}\right), 1.5$ g.L. $\mathbf{L}^{-1}\left(\mathbf{T}_{1.5}\right), 3\left(\mathbf{T}_{3}\right)$ and4.5 g.L $^{-1}\left(\mathbf{T}_{4.5}\right)$ and four levels of sprayingof garlic extract, $\mathbf{0}\left(\mathbf{G A}_{\mathbf{0}}\right)$, 25ml.L ${ }^{-1}\left(\mathbf{G A}_{\mathbf{2 5}}\right)$, 50 $\mathbf{m l} . \mathbf{L}^{-1}\left(\mathbf{G A}_{\mathbf{5 0}}\right)$ and100ml. ${ }^{-1}\left(\mathbf{G A}_{\mathbf{1 0 0}}\right)$ and their interaction. Treatments were replicated three times at factorial experiment in a completely randomized block design. The number of transplant used was 48 transplants. Powders of turmeric were soaked in distilled water for $24 \mathrm{~h}$ at $25^{\circ}$ in a lighted room to give concentrations the required. After soaking, solutions were filtered through four layers of cheesecloth then filtrate was taken to give the final water extract. The leaf mineral content were analyzed in the two successive seasons:Leaf Mineral Content: Leaf samples were collected for chemical analysis at the $1^{\text {st }}$ week of June of both seasons. Each sample consisted of 20 leaves / tree. Leaves were washed several times with tap water, rinsed with distilled water, and then dried at $70 \mathrm{c}^{0}$ until a constant weight, ground and digested according (Chapman andPratt, 1978). Nitrogen was estimated by semi-micro kieldahl method of (Plummer, 1974). Phosphorus was determined by the method outlined by (Jackson, 1973). Potassium was determined using atomic absorption spectrophotometer "Perkin Elmer 1100B" after samples digested according to (Chapman and Pratt, 1978).Iron, Manganese and Zinc weredetermined as ppm using atomic absorptionaccording to (Carter, 1993).

The obtained results were subjected to analysis of variance according to (Elsahookie andWuhaib, 1990) using L.S.D 0.05 for comparing differences between various treatment means.

\section{Results and Discussions}

Effect of Turmeric and Garlic extracts spray on Leaf N,P,K Content: Concerning the Results in Table (1) nitrogen, phosphorus and potassium content in the leaves weresignificantly affected by all treatments in both seasons, with the exception of phosphorus, which affected but not significantly. However, spraying trees with garlic extract at $100 \mathrm{ml} . \mathrm{L}^{-1}$ combined with turmeric extract at $4.5 \mathrm{~g} . \mathrm{L}^{-1}$ gave the best leaf nitrogen content $(1.99$ and $2.06 \%$ ) and potassium (2.09 and 2.13\%) for both seasons, respectively.On the other side, control was the lowest leafnitrogen content (1.22 and 1.29\%) and potassium (1.45 and 1.61\%) for both seasons, respectively.

Table (1): Effects of Turmeric and Garlic extracts sprayon leaf N, P, K contentofAnnaapple trees during 2015 and 2016 seasons.

\begin{tabular}{|c|c|c|c|c|c|c|c|}
\hline \multirow[t]{2}{*}{ Turmericg.L ${ }^{-1}$} & \multirow[t]{2}{*}{ Garlicml.L ${ }^{-1}$} & \multicolumn{2}{|c|}{$\mathbf{N}(\%)$} & \multicolumn{2}{|c|}{$\mathbf{P}(\%)$} & \multicolumn{2}{|c|}{$\mathbf{K}(\%)$} \\
\hline & & 2015 & 2016 & 2015 & 2016 & 2015 & 2016 \\
\hline \multirow[t]{4}{*}{0} & 0 & 1.22 & 1.29 & 0.18 & 0.19 & 1.45 & 1.61 \\
\hline & 25 & 1.28 & 1.33 & 0.20 & 0.23 & 1.52 & 1.62 \\
\hline & 50 & 1.40 & 1.43 & 0.20 & 0.22 & 1.62 & 1.68 \\
\hline & 100 & 1.44 & 1.49 & 0.22 & 0.26 & 1.66 & 1.77 \\
\hline \multirow[t]{4}{*}{1.5} & $\mathbf{0}$ & 1.31 & 1.39 & 0.19 & 0.22 & 1.52 & 1.69 \\
\hline & 25 & 1.52 & 1.61 & 0.23 & 0.26 & 1.71 & 1.73 \\
\hline & 50 & 1.69 & 1.80 & 0.25 & 0.29 & 1.72 & 1.80 \\
\hline & 100 & 1.55 & 1.83 & 0.26 & 0.32 & 1.85 & 1.90 \\
\hline \multirow[t]{4}{*}{3} & 0 & 1.52 & 1.61 & 0.21 & 0.20 & 1.64 & 1.75 \\
\hline & 25 & 1.66 & 1.73 & 0.25 & 0.24 & 1.79 & 1.92 \\
\hline & 50 & 1.84 & 1.98 & 0.27 & 0.30 & 1.91 & 1.98 \\
\hline & 100 & 1.93 & 1.97 & 0.33 & 0.35 & 2.02 & 2.06 \\
\hline \multirow[t]{4}{*}{4.5} & 0 & 1.66 & 1.69 & 0.22 & 0.19 & 1.70 & 1.79 \\
\hline & 25 & 1.75 & 1.70 & 0.27 & 0.26 & 1.83 & 1.88 \\
\hline & 50 & 1.88 & 1.96 & 0.28 & 0.26 & 1.97 & 2.07 \\
\hline & 100 & 1.99 & 2.06 & 0.29 & 0.33 & 2.09 & 2.13 \\
\hline \multirow[t]{3}{*}{ L.S.D 5\% } & Turmeric & 0.19 & 0.25 & N.S & N.S & 0.29 & 0.22 \\
\hline & Garlic & 0.19 & 0.25 & N.S & N.S & 0.29 & 0.22 \\
\hline & Interaction & 0.38 & 0.50 & N.S & N.S & 0.58 & 0.45 \\
\hline
\end{tabular}

Effect of Turmeric and Garlic extracts spray on leaf Fe, Mn, Zn content: Seen from the results shown in the table (2) the interaction betweenturmeric and garlic extracts spray are affected significantly, with the exception of manganese, which affected but not significantly. However, spraying trees with garlic extract at $100 \mathrm{ml} . \mathrm{L}^{-1}$ combined with turmeric extract at $4.5 \mathrm{~g} . \mathrm{L}^{-1}$ gave the best leaf iron content (210.2 and 214.4ppm) and zinc $(23.54$ and $25.53 \mathrm{ppm})$ for both seasons, respectively. On the other side, control was the lowest leaf iron content (133.2 and 138.1ppm) and zinc (16.51 and 18.87ppm) for both seasons, respectively. This result could be due to the important role of turmeric extracts that contain a carbohydrates, (50\% starch), arabinogalacton, potassium salt, essential oils and pigments, and which plays an important role in leaf mineral content (Srimal, 1997 and Alonso, 2004).And these results may be returning to the role of garlic extract, as this extract contains vitamins, minerals, flavonoids, ascorbic acid, sulphur and trace of iodine. Seventeen amino acids are found in garlic, including eight essential ones.These results are parallel with Jamali(2012) who found that spray of olive transplants with garlic extract at $50 \mathrm{mg} . \mathrm{L}^{-1}$ rates potentially increased the content of nitrogen and potassium in leaves. Abd El-Hamied and El-Amary (2015) who found that spray of pear transplants with garlic extract at $4 \%$ rates potentially increased the content of, $\mathrm{N}$ and $\mathrm{K}$ in leaves.Generally, these results are in agreement with 
Ahmed et al., (2014) who found that the turmeric extract increased leaf N, P, K content in mango trees. Armanious (2014) who worked on turmeric extract sprayin Thompson Seedless grapevines.

Table (2): Effects of Turmeric and Garlic extracts sprayon leafIron, Manganese and Zinc contentofAnnaapple trees during 2015 and 2016 seasons.

\begin{tabular}{|c|c|c|c|c|c|c|c|}
\hline \multirow[t]{2}{*}{ Turmericg.L $^{-1}$} & \multirow[t]{2}{*}{ Garlicml.L $^{-1}$} & \multicolumn{2}{|c|}{ Fe (ppm) } & \multicolumn{2}{|c|}{ Mn (ppm) } & \multicolumn{2}{|c|}{ Zn (ppm) } \\
\hline & & 2015 & 2016 & 2015 & 2016 & 2015 & 2016 \\
\hline \multirow[t]{4}{*}{$\mathbf{0}$} & 0 & 133.2 & 138.1 & 1.734 & 2.115 & 16.51 & 18.87 \\
\hline & 25 & 137.1 & 144.4 & 1.755 & 2.109 & 16.72 & 18.96 \\
\hline & 50 & 145.9 & 156.8 & 1.795 & 2.216 & 16.89 & 19.11 \\
\hline & 100 & 153.9 & 166.2 & 1.896 & 2.223 & 19.26 & 19.35 \\
\hline \multirow[t]{4}{*}{1.5} & 0 & 147.2 & 158.7 & 1.929 & 2.154 & 19.32 & 21.25 \\
\hline & 25 & 159.6 & 161.6 & 1.917 & 2.213 & 19.52 & 21.54 \\
\hline & 50 & 156.0 & 168.4 & 1.926 & 2.229 & 21.69 & 21.87 \\
\hline & 100 & 165.3 & 170.8 & 2.107 & 2.231 & 22.14 & 21.90 \\
\hline \multirow[t]{4}{*}{3} & 0 & 177.9 & 175.3 & 2.119 & 2.197 & 22.19 & 21.34 \\
\hline & 25 & 164.3 & 186.1 & 1.893 & 2.209 & 22.35 & 21.78 \\
\hline & 50 & 193.9 & 199.2 & 1.892 & 2.227 & 22.51 & 22.00 \\
\hline & 100 & 195.3 & 201.9 & 1.834 & 2.217 & 23.11 & 22.97 \\
\hline \multirow[t]{4}{*}{4.5} & 0 & 185.7 & 192.6 & 1.778 & 2.277 & 22.35 & 23.94 \\
\hline & 25 & 196.8 & 199.1 & 1.896 & 2.310 & 22.42 & 24.34 \\
\hline & 50 & 204.4 & 213.8 & 1.786 & 2.387 & 22.89 & 25.21 \\
\hline & 100 & 210.2 & 214.4 & 1.960 & 2.132 & 23.54 & 25.53 \\
\hline \multirow[t]{3}{*}{ L.S.D $5 \%$} & Turmeric & 20.26 & 23.19 & N.S & N.S & 0.42 & 0.56 \\
\hline & Garlic & 20.26 & 23.19 & N.S & N.S & 0.42 & 0.56 \\
\hline & Interaction & 40.52 & 46.38 & N.S & N.S & 0.84 & 1.12 \\
\hline
\end{tabular}

\section{References}

[1] Abd El-Hamied, Sheren A. and Eman. I. El-Amary. 2015. Improving growth and productivity of "Pear" trees using some natural plants extracts under north Sinai conditions. Journal of Agriculture and Veterinary Science. 8(1):1-9 .

[2] Ahmed, F.F; Mohamed Kh. Kamel and Hamdy I.M. Ibrahim.2014. The synergistic effects of using plant extracts and salicylic acid on yield and fruit quality of Keitte mango trees. Stem Cell, 5(2):30-39.

[3] Al-Hadethi, M.E.A and I.M, Al-Kubaisy. 2015. Response of Peento peach trees to foliar spray with someplant extracts. Zagazig J. Agric. Res., 42(5): 1029-1034.

[4] Alonso, J., 2004. Tratado de Fitofarmocos y Nutraceutices, Barcelona Corpus., p: 395-403.

[5] Armanious, Maher Kh. U. 2014. The synergistic effect of spraying some plant extracts with some macro and micro nutrients of Thompson Seedless grapevines. International Journal of Plant \& Soil Science, 3(10): 1290-1301 .

[6] Bright, J. 2005. Apple and Pear nutrition. NSW Department of Primary Industries. Primefact 85. pp. 1-12.

[7] Bruneton, J .2001. Farmacogenosia. Zaragoza (Ed.) Acriba.294-296.

[8] Carter, M.R. 1993. Soil sampling and methods of analysis, Canada Soc., Soil Sci. Lewis, London, Tokyo.

[9] Central Organization for Statistics and Information Technology (PCBS). The Ministry of Planning and Development Cooperation. Report production of summer fruit trees for the year 2013. Baghdad. Iraq.

[10] Chapman, H,D. and Pratt, P. E. 1978. Methods of analysis for soils, plants, and waters. Univ. of Calif., Div. Agric. Sci., Priced Pub., 4034.pp. 150.

[11] Dimitri, C. and L. Oberholtzer.2006. EU and U.S.organic markets face strong demand under different policies. Amber Waves. Economic Research Service .USDA, 4: 12-19.

[12] Elsahookie,M.M and Wuhaib , K.M . 1990. Design and Analysis of experiments. Univ. Of Bagh. Dar al hekma.pp.488.

[13] El-Sharony, T.F; S.F, El-Gioushy and O.A, Amin. 2015. Effect of foliar application with algae and plant extracts on growth, yield andfruit quality of fruitful mango trees cv. FagriKalan. Journal of Horticulture. 2(4):1-6.

[14] FAO. 2012. FAO. Statistics Division 2013.

[15] Jackson M. H. 1973. Soil chemical analysis. Prentice Hall. Inc., N. J.; Private Limited and New Delhi.pp. 508.

[16] Jamali, N.M. 2012. Effect of using element and plant extracts on growth ofOleaeuropaeu.Scientific Journal of the University of Karbala. 3(2): 90-93.

[17] Plummer, D. T. 1974. An Introduction to Practical Biochemistry. MC Gram - hill book company (UK) limited. England.

[18] Srimal, R.C., 1997. Turmeric a brief review of medicinal properties. Fitoterapia, 68(6): 483-494. 